\title{
Relationship Between Religiosity and the Level of Moral Reasoning of High School Student
}

\author{
Fidya Alvi Mufida \\ Faculty of Psychology and Health, Islamic University Ampel Surabaya \\ fidyalvi@gmail.com
}

\begin{abstract}
The purpose of this study was to determine the relationship between religiosity and the level of moral reasoning of high school students. This research is correlation research using data collection techniques in the form of a religiosity scale and moral reasoning scale. The results of this study indicate that there is a relationship between religiosity and students' level of moral reasoning Senior High School, with a correlation coefficient of (-0.049) with a significance of 0.668. This shows that there is no significant relationship between religiosity and the level of moral reasoning of high school students. Based on the negative coefficient price, the higher the level of religiosity followed by the low level of moral reasoning, and vice versa, the higher the level of moral reasoning followed by low religiosity in high school students.
\end{abstract}

\section{Keywords: Level of Moral Reasoning, Religiosity}

\section{Preliminary}

Adolescence as a period of movement of children to adults through various dynamics, where growth tends to be more optimal in terms of physical whereas in the stage of psychological maturity tends to be less. Teenagers are more sensitive to experiencing conflicting values and expectations that can complicate themselves while changing their roles. Adolescents are individuals who experience a series of specific developmental tasks (Oemar Hamalik, 2002).

The task of important developments that must be passed by adolescents is one of them to learn what is expected by the group from him and then be able to shape behaviour by social expectations without being guided, supervised and threatened with punishments such as when children. Adolescents are demanded by the environment to adjust social conditions, adjustments with friends, and adjustments to prevailing morals. In this case, adolescents, social and moral self develops so that they give birth to other moral values (Budiningsih, 2004). Adolescents must be able to control their behaviour and be able to replace moral concepts in childhood with generally accepted moral principles and formulate them into moral codes as guidelines for behaviour. Although in the process, the development of adolescents does not always run in a linear, straight or potential direction, expectations and values adopted, because of the many inhibiting factors that are internal and external (Yusuf, 2002).

The age of adolescence is marked by the occurrence of major changes in various biological, cognitive, socio and emotional aspects (Santrock, 2003). Teenagers are generally at the high school level. The age at which children begin to integrate with the community, adolescents no longer feel below the level of adults but are at the same level of at least rights issues.

The effect of accelerating growth has implications for psychosocial adolescents, namely; adolescents will experience inner conflicts over the demands of the community for them to do adult work, which according to them is capable of doing so, even though in reality teenagers cannot. Teenagers will experience inner anger when they see abnormalities or physical, social irregularities because adolescents are aware that appearance is one of the main social stimulants. With the existence of physical maturity in a religion called "baligh" adolescents are obliged to carry out compulsory worship such as prayer as harmony between religion and daily life. (Ainur, 2005). Thus religion has an important role in one's moral control. But it must be remembered that the notion of religion is not automatic as moral. How 
many people understand religion, but their morale decreases. And not a few people who do not understand religion at all, but the morals are quite good (Hamim, 2015).

The current reality shows the occurrence of various moral violations among teenagers who are the majority as school students, such as the use of narcotics, the involvement of brawls between students, violations of school rules, ditching and hanging out on the roadside, pornography and deprivation of other people's property rights to date this. One of them was the incident that happened to KR of Taruna Nusantara High School students in South Jakarta who died allegedly killed by their own friends (m.detik.com Friday, March 31 2017).

Murder events between high school students, researchers also obtained data on cases of student morality deviation in school through an interview observation process with high school BK teachers in Surabaya during an internship. In reality everyday violations of school regulations often occur, there are students who carry out various forms of school rules including delays in schooling, uniforms not according to rules, student involvement in student brawls, theft in the school environment and involvement in narcotics use cases (Report UINSA 2016 educational psychology guidance and counselling internship).

Often juvenile deviant behaviour is due to moral immaturity that has an impact on personal and social adjustment. Some teens ignore legal regulations, and some cannot learn which is good and wrong and sacrifice parental standards if it is guaranteed to get social support from their peers. Many teenagers who justify the actions they know are wrong by saying that everyone shoplifts, cheats or uses illegal drugs (Hurlock, 1980). Seeing the phenomenon, the world of adolescence seems to be a worrying spectre because it is very vulnerable to negative influences., while adolescence is a period of moral development began conceptualized.

Morality as a habit for someone to behave better or worse in thinking about social problems, especially in moral actions, has explained the theory of Piaget's moral development than continued by Lawrence Kohlberg in three levels, each of which is divided into two stages so that it becomes six stages as a whole. Kohlberg's concept emphasizes that the determinant of moral maturity is influenced by how individuals reason not because of a response to a behaviour, as well as moral maturity in adolescents. This statement is reinforced by Rest which states that education and IQ have a consistent relationship to moral reasoning, where education and IQ are indicators indirect from cognitive development (Rest, 1979).

When entering adolescence, children no longer receive moral codes from others. They form their own moral code based on the concept of right and wrong that has been changed and improved to fit the level of development that is more mature and equipped with laws and regulations learned from parents, teachers. Some adolescents even complete morals with religious knowledge or religiosity (Langford, P.E, 1975). Thus religion has become a guideline that is directly used by adolescents for their moral understanding. Religiosity is a source of moral standards that is important for directing a person's behaviour. According to Glock \& Stark, religion is a symbol centred on the reasoning that is lived out as the most meaningful (Ancok \& Suroso, 1994). Every religion must claim truth, so also in Islam which considers moral (moral) as the main goal of the Islamic message.

Kohlberg explained that moral behaviour would be so narrow if it were only limited to moral behaviour that could only be seen. Moral behaviour includes things that cannot be seen. Moral reasoning to decide on carrying out a moral act is moral behaviour that cannot be seen, but can be measured. Correct moral measurement is not just observing moral behaviour that appears, but having to look at moral reasoning will be able to know the high and low moral (Budiningsih, 2004).

There are five factors that can influence the development of one's moral reasoning, namely the opportunity to transfer roles, moral situations, cognitive moral conflict, family and education. Also, other factors that influence moral reasoning include patterns of parenting, schooling, interaction with peers and culture. Kohlberg believes all these experiences work by dealing with cognitive challenges that stimulate them to think about moral issues in a more complicated way (Kohlberg in Berk \& Laura 2012).

Morality has been examined in various perspectives of other supporting variables, one of them as in Wahyuni's (2012) study, a person is said to be moral if he has a moral awareness that is able to judge good and bad things, things that can be done and not done and which are ethical and unethical. A moral person will naturally appear in moral judgment or reasoning and in good, right and ethical behaviour. That is, there is a unity between moral reasoning and moral behaviour. In other words, how beneficial a 
moral behaviour is to human values, but if the behaviour is not accompanied and based on moral reasoning, then the behaviour cannot be said to be a behaviour that contains moral values.

Many of the efforts made to study moral values are through education. Education is one of the efforts to deliver students to the process of maturity in various aspects. Schools as educational institutions have two main functions, namely education and socialization institutions. Based on these two functions, the influence of school on students is not only limited to the transfer of knowledge, but the atmosphere of the school environment and the education system applied will also affect the personality function of students (Furhmann, 1990).

This is by Law No. 20 of 2003 concerning the national education system in article 3, which states that national education functions to develop capabilities and shape the character and civilization of a nation that has motivation to educate the life of the nation. One of the goals of National Education is to develop the potential of students to become human beings who believe and fear God Almighty, have a noble character, are healthy, knowledgeable, capable, creative, independent and become democratic and responsible citizens. (Law of the Republic of Indonesia No. 20 of 2003 concerning the Education System).

In contrast to the explanation in the Republic of Indonesia Law No. 20 of 2003 concerning the education system. The 2016 Minister of Education and Culture Regulation on the Basic and Secondary Education Content standards chapter II on Competency Levels explains that competency levels are generic competency criteria that must be met by students at every level of education to achieve Graduates' Competency Standards. Competency levels are developed based on criteria; (1) Level of development of students, (2) Qualifications of Indonesian competencies, (3) Mastery of competency that is tiered. Also, the Competency Level also pays attention to the complexity or complexity of competencies, educational unit functions and integration between relevant levels. The competencies of the secondary education level of high school consist of core competencies, spiritual attitudes, social attitudes and knowledge attitudes. This is by one of the objectives of National Education.

The education system in schools is very important in helping the process of improving the moral reasoning power of a student, both between students and teachers, as well as students with friends, for this reason providing moral education to students is still needed at any time. Religious education through various institutions and media has not been able to achieve the results as expected. Religion, with its teachings and values, is still something formal. Strictly speaking, for many parties, diversity has not been correlated with its social behaviour (RI Ministry of Religion, 2004).

Islamic Education is Education based on Islam. Thus when referring to the definition of education as mentioned above, Islamic education is a process of guidance and conscious effort carried out by education or an authorized institution in education to provide direction and change to students (by that education) to be persons of character, personality and behave in accordance with Islamic teachings (Nata, 2010). In school, students get Islamic education through Islamic studies, and internalize the values of morality in both the lessons and the culture of the school environment.

Based on this, it can be said that the functions and roles of morality and morality are the same, namely determining the law or value of an act done by humans, to determine the value of good or bad, but morality and morals are different. The difference lies in the source that is used as a benchmark to determine good and bad. Morality comes from habits that are generally accepted in society, while morals are based on the Qur'an and al-hadith.

Ansari (1986) defines religion, religion or din, as a system of belief or faith on the basis of something that is absolutely beyond human beings and is a system of human worship to those who are considered absolute, and a system of norms that regulate the relationship between humans and humans, humans and other natural with the ordinances of faith and the ordinances that have been arranged. Whereas according to Darajat (1997), religiosity or religion can provide an individual way out to get a sense of security, courage, and not worry about facing the problems of life. Islam teaches that by getting closer to Allah, someone will get inner and outer calm and can control their behaviour.

To overcome the moral dilemma of life, many people make the idea of religion or religiosity one of the ways to teach moral values. Religious education and youth activities teach directly concern for others and provide opportunities for moral discussion. Teenagers who are connected with something higher can develop certain inner strengths, including self-moral relevance and prosocial values, which help them translate their thoughts into action. (Hardy \& Carlo, 2005; Sherrod \& Spiewak, 2008 in Laura E, Berk, 2012). 
In every school, there are many youth organizations, one of which is a spiritual organization for each religion, one of them is Islam. Through religious organizations, students can discuss moral issues and their relationship with them so that adolescents are balanced in assessing moral issues and can behave by applicable moral standards.

Religiosity involves cognitive processes that affect morality. Wahman (1981) argues that religious dogma is related to religiosity and influences morality. Some studies focus on how factors influence morality; a study shows that religiosity is related to moral reasoning. Batson, (1976: 1989) found that people who feel they have the urge to find the truth of religion and faith tend to use moral reasoning according to the highest stages of Kohlberg's theory and have more altruistic motivation.

Young, Cashwell and Woohington's (1998) research shows that there is a correlation between religion, spirituality and the level of moral reasoning. They also found that spirituality had a strong influence on meaningfulness; this was by Batson's idea that the urge to find the truth of religion was related to the level of moral reasoning. This is in line with other studies that relate religiosity, religion and moral behaviour to have positive results that can underlie the process and influence of religion if adapted to social processes on measures of moral behaviour and attitudes (King \& Ames, 2004).

Research (Ahmadi, 2013) explains that there is a relationship between the level of moral development and the behaviour of religiosity, emotion and adherence to religious teachings have a negative relationship, although at the conclusion that the increase in moral and emotional development and adherence to religious teachings will increase.

Research conducted by Hasset 1981 (in Atwater, 1992) on morals shows that there is a significant relationship between religiosity or religion and moral behaviour. Respondents who have high religiosity scores and moral behavioural scores are only produced by several people, while others have different scores between religiosity scores and moral behaviour scores. This means that the relationship between religiosity and moral behaviour is more shown in institutional behaviour than personal behaviour.

The results of the research conducted (Yoga, 2016) related to differences in moral reasoning carried out on the subject of religious and public school-based school students, indicating the moral level of students attending Islamic-based schools is higher than students who attend public schools. Although based on the average value, in general, the moral level of students attending Islamic-based schools and public schools is in the high category. Other research conducted by (Immawan, 2004) shows that school students based on Islamic Madrasah Tsanawiyah have a higher level of moral reasoning than public school students. Based on these studies, it can be seen that the school environment with Islamic-based education influences aspects of religiosity and increased reasoning student morale. In this study, researchers chose high school students as a research population to prove whether the school environment and education were the main factors in increasing students' moral reasoning in terms of religiosity of Islam.

Education is very meaningful as a habit for the child to behave according to what is expected since he moved taklik or mumayyiz and can think to become a mukallaf, gradually entering adolescence or adulthood and ready to face the next life. Thus it will make children grow up with a healthy soul, which always draws close to good things and is afraid of doing negative things because they believe that God is always watching him in his behaviour and actions. Healthy moral development taught by his parents from an early age can deliver children to success in the future on the instructions of Allah S.W.T, as His word in the letter Al-Qasas: 50 which means "And who is more astray than the one who follows his desires by not getting a hint from God at all." (Ainur, 2005).

The development of a person's religious awareness, including adolescents, is influenced by several factors, including; innate factors (internal) and environmental factors (external). Religious development in adolescents can be increased through knowledge sourced from education, parental guidance, peer and other discussions, the holy book of the Koran and reading books (Ainur, 2005).

Based on the previous explanation, it can be seen that adolescents are individuals who experience complex developments with various obstacles that must be overcome. Demanded to be able to form the concept of moral reasoning in order to form behaviours that can distinguish good and bad by still observing the teachings of Islam. Adolescence as a development process in which there is a process of "baligh or mummy" in which individuals or adolescents are mature and able to distinguish between good and bad which are expected to be able to harmonize the guidance of religion and behaviour of morality through reasoning. Therefore researchers will examine how religiosity can affect the level of moral reasoning in high school students. 
Educational institutions that will be studied in this study are educational institutions with general and Islamic education backgrounds, namely High School (Senior High School) which is an educational institution under the guidance of the Ministry of National Education under the auspices of the Islamic Foundation. Giving subjects in high school is balanced between general subjects from religious subjects.

Based on this background, and in line with the concept that schools with general or religious education can form students who have extensive and deep knowledge, have good moral behaviour while religion which in this case is a school with a religious background can influence someone's moral reasoning. Then the researcher conducted a study with the formulation of the problem, namely, is there a relationship of religiosity with the level of moral reasoning in high school students.

\section{Research Methods}

Moral reasoning is seen as a basic concept possessed by individuals to analyze social problems and to first assess what actions they will take, with different stages in each of their developments, Kohlberg's stages of moral reasoning are used as the basis for Prof.'s scale of moral reasoning. Dr C. Asri Budiningsih which will be used in this study a) Pre-conventional Level; 1) Stage of punishment orientation and compliance, 2) Stage of instrumental relativist orientation. b) Conventional Levels; 1) Interpersonal agreement orientation stage, 2) Stage of legal orientation and order. c) Post-conventional level; 1) Stage of social contract orientation legality, 2) Stage orientation of universal ethical principles.

Religiosity is a spiritual feeling and religious belief that encourages a person to behave in accordance with the level of his obedience to religion and helps him organize into daily life. The dimensions in religiosity are; a) The dimensions of belief can be equated with aqidah. The dimensions of the belief or creed of Islam refer to the level of belief of a Muslim in the truth of the religion of his religion, especially in terms of fundamental and dogmatic teachings. In Islam, the contents of this dimension involve beliefs about God, angels, Apostles, the book of Allah, surge and hell and qadha and qadar; b) The dimensions of Teradata or religious practice are aligned with sharia; c) The dimension of worship or sharia refers to the degree of compliance of a Muslim in working on ritual activities as instructed and encouraged by his religion. In Islam, the dimension of religious practice concerns the implementation of prayer, fasting, almsgiving, pilgrimage, reading the Qur'an, prayer, remembrance, sacrifice, reconciliation in the mosque during the fasting month and so on; d) The dimensions of experience or appreciation are aligned with the dimensions of experience or religion referring to how far the level of a Muslim feels and experiences religious feelings and experiences. In Islam, this dimension is manifested in feelings of being close or familiar with God, feelings of prayers are often answered, feelings of peace and happiness because of Allah, feelings of trust in God, feelings of gratitude and feelings of getting help or warning from Allah; e) Dimensions of religious knowledge equated with science The dimensions of religious or scientific knowledge refer to how the level of knowledge and understanding of a Muslim is exposed to his religious teachings, especially regarding the basic teachings of his religion, as contained in his holy book. In kebeerislaman, this dimension involves knowledge of the contents of the Koran, the main points of the teachings that are straightforwardly believed and carried out (pillars of faith and pillars of Islam), Islamic laws, Islamic history and so on; f) The dimensions of practice are aligned with morals The dimensions of practice or morals refer to how the level of a person who behaves is motivated by his religious teachings, namely how individuals relate to their age, especially with other humans. In the Islamic dimension, this includes helpful behaviour, cooperation, charity, prosperity and growth of others, fairness, honesty, forgiveness, protecting the environment, trust, obeying the norms of Islam and so on. The religiosity variable in this study will be measured using a religiosity scale compiled by researchers using that dimension.

In this study, the population to be studied are high school students who will be selected according to the characteristics as a consideration of the sample. Samples are a portion of the population taken in a representative or representative population or a small part of the population observed. (Iskandar, 2009) with the characteristics of the research sample; a) Middle teens (15-18 years), b) Muslim, c) Status as a high school student.

The taking method in this research is probability sampling with simple random sampling technique, random or random sampling allows each to have the opportunity to become a research sample, using rendering. Assuming the sample is homogeneous or the same (Iskandar, 2009) Using the 
Krejcie-Morgan table principle with an error rate of $5 \%$. With a population of high school students of approximately 100 students, the sample in this study amounted to 80 students (Usman, 2003).

In this study, data collection was obtained using a measuring instrument or research instrument in the form of a psychological scale. The measuring tool is a method of collecting data in research activities that have the purpose of revealing facts about the variables under study (Hadi, 2000). The measuring instrument used in this study is a scale. The scale of moral reasoning in this study was adapted from the research instruments of Prof. Dr C. Asri Budiningsih (2008). This scale of moral reasoning is taken from the interview guidelines in the form of moral dilemmas compiled by Kohlberg in the form of short stories containing moral issues to be solved. The purpose of this scale is to reveal the subject's moral reasoning about what actions should be taken if the subject is in a situation like the one played in the story.

The Religiosity Scale is used to measure the free variable, namely religiosity. This scale was compiled by researchers based on the dimensions of Glock and Stark, which were adapted to the concepts of Ancok and Suroso, to fit the concept of Islam.

The data obtained will be analyzed quantitatively using statistical calculations. In this study, the whole process of statistical calculation was carried out using the help of a computer program statistical package for the social science (SPSS) 16.0 for Windows.

In this study, researchers used several methods of data analysis, among others; 1) A normality test is carried out to find out whether the distribution of research data has spread normally. This normality test uses Kolmogorov-Smirnov's One Sample. The One-Sample Kolmogorov-Smirnov procedure is used to test the null hypothesis of a sample for a particular distribution. According to Hadi (2000), if the significance is $>0.05$ then the distribution of data is normal, whereas if the significance is $<0.05$, the distribution data is not normal; 2) Linearity test is used to find out whether the distribution of research data, namely independent variables (religiosity) with dependent variables (moral reasoning) has a linear relationship. Linearity test was carried out using $\mathrm{F}$ test analysis (ANOVA). The $\mathrm{F}$ test statistical analysis will produce the $\mathrm{F}$ count. Linear data criteria are if $\mathrm{p}>0.05$, the results are significant, meaning the regression line is linear, and vice versa; 3) Testing the hypothesis of this study using the Spearman correlation analysis technique of the SPSS program to determine the relationship between independent variables and dependent variables and prove the hypothesis of a relationship between religiosity and the level of moral reasoning of high school students. Spearman correlation test is used for correlation testing, whose data is ordinal or tiered and free to distribute. If the correlation is positive, the relationship between the two variables is in the same direction or proportional, which means that the higher the religiosity, the higher the level of moral reasoning. If the correlation is negative, then the higher the value of religiosity, the lower the level of moral reasoning and vice versa. Correlation coefficient values range from 0 to 1 , the closer to number one, the stronger the relationship between the two variables, to test the hypothesis the significance rules are used $>0.05$, then Ho is accepted, and significance $<0.05$ Ho is rejected (Muhid, 2012).

\section{Research Result}

From the results of hypothesis testing, there is no relationship between religiosity and the level of moral reasoning of high school students. Based on the price of the correlation coefficient of $(-0.049)$ which is negative, it means indicating the direction of the opposite relationship where there is a relationship between the higher student religiosity followed by, the lower level of student moral reasoning, and vice versa. Although overall data categorized by Yapita Senior High School students have a very low religiosity score of $0 \%$, low category $0 \%$, a moderate category with 3 students and a percentage of $3.75 \%$, high category with 39 students and $48.75 \%$ and categories very high with 38 students and a percentage of $47.5 \%$. While at the level of moral reasoning there are as many as five students at the preconventional level of $6.25 \%, 64$ students with conventional levels and $80 \%$ percentages and 11 students at the conventional post level with a percentage of $13.75 \%$.

Although basically in this study the data found that the categories of subjects in the level of religiosity were moderate with several three students and a percentage of $3.75 \%$, a high category with 39 students and a percentage of $48.75 \%$ and a very high category with 38 students and 47 per cent. , $5 \%$. While at the level of moral reasoning there are as many as five students at the pre-conventional level of 
$6.25 \%, 64$ students with conventional levels and $80 \%$ percentages and 11 students at the conventional post level with a percentage of $13.75 \%$.

\section{Discussion}

The results of this study are by Kohlberg's conception that there is no relation of religiosity to individual moral reasoning. Kohlberg explained that between religiosity and moral reasoning are two parts of a separate development process; religiosity is a process arranged based on revelation while moral reasoning is arranged based on arguments about justice. The argument is said to be influenced by higher levels of cognitive development and exposure to moral experience and the ability to deal with debate or conflict, one of which is the process through higher education (Kohlberg, 1981). Kohlberg's concept emphasizes that determinants of moral maturity are influenced by how individuals reason not because of a response to behaviour, as well as moral maturity in adolescents.

This research is reinforced by the results of a study conducted by Sukmaya entitled The Effect of Religiousism on the Reasoning of Youth Moral in Islam, which shows that there is no influence between religiosity and moral reasoning in adolescents. Also, research conducted by Forsyth (1980) shows that spiritualists are more idealistic than people who are less spiritual. While very spiritual people don't tend to be relativistic than people who are less spiritual, it shows that spiritual is not related to moral reasoning.

Research conducted by Hasset 1981 (in Atwater, 1992) on morals shows that there is a significant relationship between religiosity or religion and moral behaviour. Respondents who have high religiosity scores and moral behavioural scores are only produced by several people, while others have different scores between religiosity scores and moral behaviour scores. This means that the relationship between religiosity and moral behaviour is more shown in institutional behaviour than personal behaviour.

Based on the findings of this study, several previous studies and the main concepts related to moral reasoning can be seen that other variables or supporting variables are needed to find out the relationship related to religiosity with the level of moral reasoning.

The absence of the influence of religiosity on moral reasoning shows that there are other factors that influence moral reasoning and make effective contributions that are greater than religiosity. According to Kohlberg, moral reasoning is influenced by high levels of cognitive development and sociomoral experiences (Glover, 1997). This statement is reinforced by Rest which states that education and IQ have a consistent relationship to moral reasoning, where education and IQ are indirect indicators of cognitive development (Rest, 1979)

In the development of research subjects who are middle teens with ages 15 to 17 , in concept according to Piaget are included in the Autonomous morality stage, namely the second stage at the age of 10 years or more, where a child begins to realize that rules are man-made and that in judging a actions, intentions of the offender and their consequences need to be considered. That in the reasoning process is closely related to individual cognitive processes. Although there are other things that affect the level of one's moral reasoning such as moral climate, the opportunity for role transfer, socio-cognitive conflict, parenting, schooling, peer interaction, culture and human nature, namely the ability to control oneself in acting, gender, level education, from several conceptual factors that influence moral reasoning, religion plays an important role in the process of controlling moral reasoning, so it needs to be understood how the role of religion in morality, and religion can be a moral controller. So that it can be seen how closely the relationship between religion and worship and morality.

This is evidenced in this study that we need to develop a way to find out the link between religiosity and moral reasoning. Because the process of moral development is related to rules and conventions about interactions in the cognitive, behavioural and emotional domains. In the cognitive domain describes how individuals reason or think about rules for ethical behaviour. In the behavioural domain, explain how individuals behave in an actual way, not on the morality of their thinking. In the emotional domain emphasizes how individuals feel morally like, do they have strong feelings of guilt in refraining from taking immoral actions (Santrock, 2003).

It should be noted that the relationship between moral reasoning and other variables to see the relation with religiosity, the use of instruments or measuring instruments need to be considered in the process of knowing the relationship between the level of moral reasoning and religiosity. Because the use of instruments also affects the results of the data obtained. 


\section{Conclusion}

The conclusion in this study proves the absence of a relationship of religiosity with the level of moral reasoning of high school students. Based on the price of the correlation coefficient of (-0.049) which is negative, it means indicating the direction of the opposite relationship where there is a relationship between the higher student religiosity followed by, the lower level of student moral reasoning, and vice versa. With this research, it is expected to be a school reference in developing the school climate related to student religiosity and morality.

\section{Daftar Pustaka}

Ancok, D. Suroso, F.N. (1994). Psikologi Islami : Solusi Islam atas Problem-Problem Psikologi. Yogyakarta : Penerbit Pustaka Pelajar.

Ahmadi, Abu. (2003). Ilmu Pendidikan. Jakarta: Rineka Cipta

Ainur,Arif. (2005). Sistematika Psikologi Perkembangan Islami. Surabaya:ARKOLA

Anshari, S.E. (1986). Wawasan Islam. Jakarta : PT Rajawali Press.

Atwater, E. (1992). Adolescence. New Jersey: Prentice Hall Englewood Cliffs.

Batson, C. D. (1976). Religion as prosocial: Agent or double agent. Journal for the Scientific Study of Religion.

Berk, Laura E. (2006). Child Development. USA: Perason Education, Inc.

Budiningsih, A. (2004). Pembelajaran Moral. Jakarta : PT Rineka Cipta.

Daradjat, Z. (1997). Peranan Agama dalam Kesehatan Mental. Jakarta : CV Haji Masagung.

Departemen Agama RI. (2004). Pedoman Pendidikan Agama Islam di Sekolah Umum.

Jakarta:Direktorat Jenderal Kelembagaan Agama Islam. Direktorat Madrasah dan Pendidikan Agama Islam pada Sekolah Umum.

Forsyth, D. R. (1980). A taxonomy of ethical ideologies. Journal of personality and social psychology. 39, $175-184$

Furhmann, B.S. (1990). Adolescence. London: Scott, Foreman and Company.

Glover, R. J. (1997). Relationship in Moral Reasoning and Religion Among Member of Conservative, Moderate, and Liberal Religious Groups.The journal of social psychology. 137 (2), 247-254.

Hadi, S. (2000). Metodologi Research.. Yogyakarta : Penerbit Andi Yogyakarta.

Hurlock, Elizabeth. (1980). Psikologi Perkembangan. Suatu Pendekatan Sepanjang Rentang Kehidupan. Jakarta: Erlangga.

Hurlock, E.B (1990). The Psychology of Religion: An Empirical Approach. New York: Guilford Press.

Immawan, Zidni. (2004). Penalaran Moral Pada Siswa SLTP Umum Dan Madrasah Tsanawiyah. Humanitas: Indonesian Psychological Journal Vol.1 No. 2 Agustus 2004:25-32 Fakultas Psikologis Universitas Wangsa Manggala 
King. P.M, \& Ames. L.F., (2004). Religion as a Resources for Positive Youth Development: Religion, Social Capital and Moral Outcomes. Developmental Psychology, 40. 703-713.

Kohlberg, L., (1981). The Philosophy of Moral Development. San Fransisco: Harper and Row.

Langford, P.E. S. Goerge. (1975). Intellectual and moral development in adolescence. British Journal of Educational Psychology.

Muhid,Abdul (2012). Analisis Statisktik : 5 Langkah Praktis Analisis Statistik Dengan SPSS for Windows. Sidoarjo: Zifatama.

Nata Abuddin.(2010). Ilmu pendidikan Islam. Jakarta:kencana.

Peraturan Menteri Pendidikan dan Kebudayaan Tahun 2016 tentang Standar Isi Pendidikan Dasar dan Menengah bab II mengenai Tingkat Kompetensi

Rosyidi, Hamim (2015) Psikologi Agama. Surabaya: Jaudar press.

Rest, J. R., 1979. Received Manual for The Defining Issues Test. USA: Minneapolis, Minnesota Moral Research Projects.

Santrock, W, John (2003) Adolence perkembangan remaja. Jakarta : Erlangga.

Undang-Undang Republik Indonesia No. 20 Tahun 2003 tentang Sistem Pendidikan.

Yoga, Okta, (2016), Perbedaan Tingkat Moral Siswa Antara Sekolah Berbasis Islam dengan Sekolah Umum. Naskah Publikasi Twinning Programe. Fakultas Psikologi dan Fakultas Agama: Islam Universitas Muhamadiyah surakarta.

Young, S. J., Cashwell, C.s., \& Woolington, J.V. (1998). The relationship of spirituality to cognitive and moral development and purpos life e in: An exploratory investigation. Counselling and Values, 43 91), 63-70.

Wahrman, I. S. (1981). The relationship between dogmatism, religious affiliation, and moral judgment development. The Journal of Psychology, 108, 151-154.

Wahyuni, Tri (2012). Hubungan Antara Tingkat Penalaran Moral Dengan Kedisiplinan Siswa SMKN 1 Sragen. (Naskah Publikasi) Surakarta FakultasPsikologi 